\title{
Quantification of the morphodynamics and ecological functionality of a Mediterranean river
}

\author{
Margot Chapuis ${ }^{1, *}$, Amine Ait Elabas ${ }^{2}$, Katia Souriguère $^{3}$, Franck Compagnon ${ }^{3}$, Vincent \\ Mayen ${ }^{4}$ and Benoît Terrier $^{5}$ \\ ${ }^{1}$ Université Côte d'Azur, CNRS, ESPACE, France \\ ${ }^{2}$ Université Lumière - Lyon 2, UFR Temps et Territoires, 69007 Lyon, France \\ ${ }^{3}$ SMIAGE Maralpin, 06201 Nice cedex 3, France \\ ${ }^{4}$ Agence de l'Eau Rhône Méditerranée Corse, Délégation Paca \& Corse, 13001 Marseille, cedex 01, \\ France \\ ${ }^{5}$ Agence de l'Eau Rhône Méditerranée Corse, Direction de la planification et de la programmation, \\ 69363 Lyon, cedex 07, France
}

\begin{abstract}
The Var River (South-East France) was extensively modified (channelization, dams...) on the $21^{\text {th }}$ century and is currently undergoing an ambitious restoration project to restore its 'natural' active braiding pattern on the downstream reach of the river. As part of the feedback evaluation of the project, this study aims at: (1) quantifying the morphological evolution of the bed that is recovering from sediment discontinuity; (2) identifying and/or developing hydromorphological and ecological indicators which quantify improvement in the river system from hydrosedimentary and ecological points of view. We used LiDAR and orthophoto datasets and performed analyses for unchannelized braiding rivers $[1,2]$. Active width $\left(W_{\text {restored }}=242 \pm 19 \mathrm{~m}\right.$ vs. values ranging from $103 \pm 53$ to $163 \pm 53 \mathrm{~m}$ for 'unrestored' reaches) and normalized bed relief index values $\left(B R I^{*}\right.$ restored $=0,003 \pm 0,001 \quad$ vs. $0,003 \pm 0,003$ to $0,007 \pm 0,004$ for 'unrestored' reaches) indicate a combination of low roughness and wide active width. Thus the 'restored' reach shows a different set of indices compared to nearby 'unrestored' reaches, suggesting these tools are promising in discriminating 'restored' vs. 'unrestored' reaches. Adapting existing methods from 'natural' to 'channelized' braiding rivers widened the potential application of the tools developed by Lallias-Tacon [2] to modified braiding river systems.
\end{abstract}

\section{Introduction}

French Mediterranean rivers are complex systems that are defined by several physical characteristics $[3,4]$ :

- Most of summer the climate is dry with high temperatures and low or no precipitations. Winters are mild and wet.

\footnotetext{
* Corresponding author: margot.chapuis@unice.fr
} 
- Contrasted hydrology with low flows in summer as opposed to heavy rain, sometimes triggering violent floods, during fall and spring (sometimes strengthened by snowmelt).

- River basin landscapes show steep topography and low vegetation cover, often leading to high sediment supply. Sediment supply is generally coarse even in the lowland areas because of the steepness of the longitudinal profile.

- High diversity of habitats and micro-habitats for aquatic flora and fauna.

- Highly impacted environments, as land use planning (channelization, hardening, gravel mining...) sometimes started centuries ago, initially to secure water access throughout the year or to prevent flooding risk and lateral migration.

- Specific bed morphology, very active and usually historically braiding, resulting from all the above characteristics: floods can rework the bed to maintain it large in order to drain water and sediment discharges. On the contrary, standard flows are concentrated in a small surface of the floodplain.

Mediterranean rivers are thus often characterized by high lateral variability and frequent sediment bed reworking during floods. Bed mobility is the best way to maintain biodiversity and biological quality of the riverine landscapes [5] because local communities depend on the spatial and temporal variability of habitats and their connectivity across watersheds [6-7, in 8]. Consequently, restoration projects are often based on the fact that these river systems potentially have 'self-restoration' ability at high flows [3]. Restoration projects are generally expected to deliver multiple benefits to river systems [9]: flooding risk mitigation, restoration of open landscapes that benefit biodiversity, 'natural' and economical mitigation of vegetation encroachment, and groundwater and surface water connectivity can be achieved through active braiding pattern and sediment continuity restoration.

In the French Mediterranean region, other channelized rivers have also had their braiding pattern degraded during recent decades (Durance, Bléone... [10]). River managers need to quantify their braiding pattern in order to assess their morphodynamics and ecological functionality and to evaluate the benefit of restoration projects.

As part of the ongoing feedback evaluation of such projects, this study aims at:

- Integrating recent progress in LiDAR processing on the specific case study of the Var River, by quantifying the morphological evolution of the bed after the lowering of weirs' level.

- Improving our understanding of sediment morphodynamics of a channelized river that is recovering from sediment discontinuity and restoring a braiding pattern within the embankment width.

- Identifying and/or developing hydromorphological and ecological indicators which quantify improvements in the braiding pattern from both hydrosedimentary and ecological points of view.

\section{Methodology and field site}

\subsection{Field site}

The Var River is a 110-km long gravel-bed river, ending in the Mediterranean Sea near Nice (fig. 1). The downstream floodplain is only $25 \mathrm{~km}$ long since the river exits steep gorges just a few km before its last significant tributary (the Estéron River, fig. 1). The Var upper catchment (total area: $2822 \mathrm{~km}^{2}$ ) is located in the Southern French Alps and is 
characterized by steep slopes, but the downstream reach slope is only of 1 to $5 \%$ with a braiding pattern. Braiding prevents accurate measurement of water discharge: maximal estimated flood is $3000 \mathrm{~m}^{3} / \mathrm{s}$, while mean annual flow is estimated at $52 \mathrm{~m}^{3} / \mathrm{s}$. Flooding and ecological functions are mainly driven by bed morphology evolution in braiding systems. The lack of accurate discharge measurements in these rivers does not prevent river management, which relies more on topography than on hydrologic analyses.

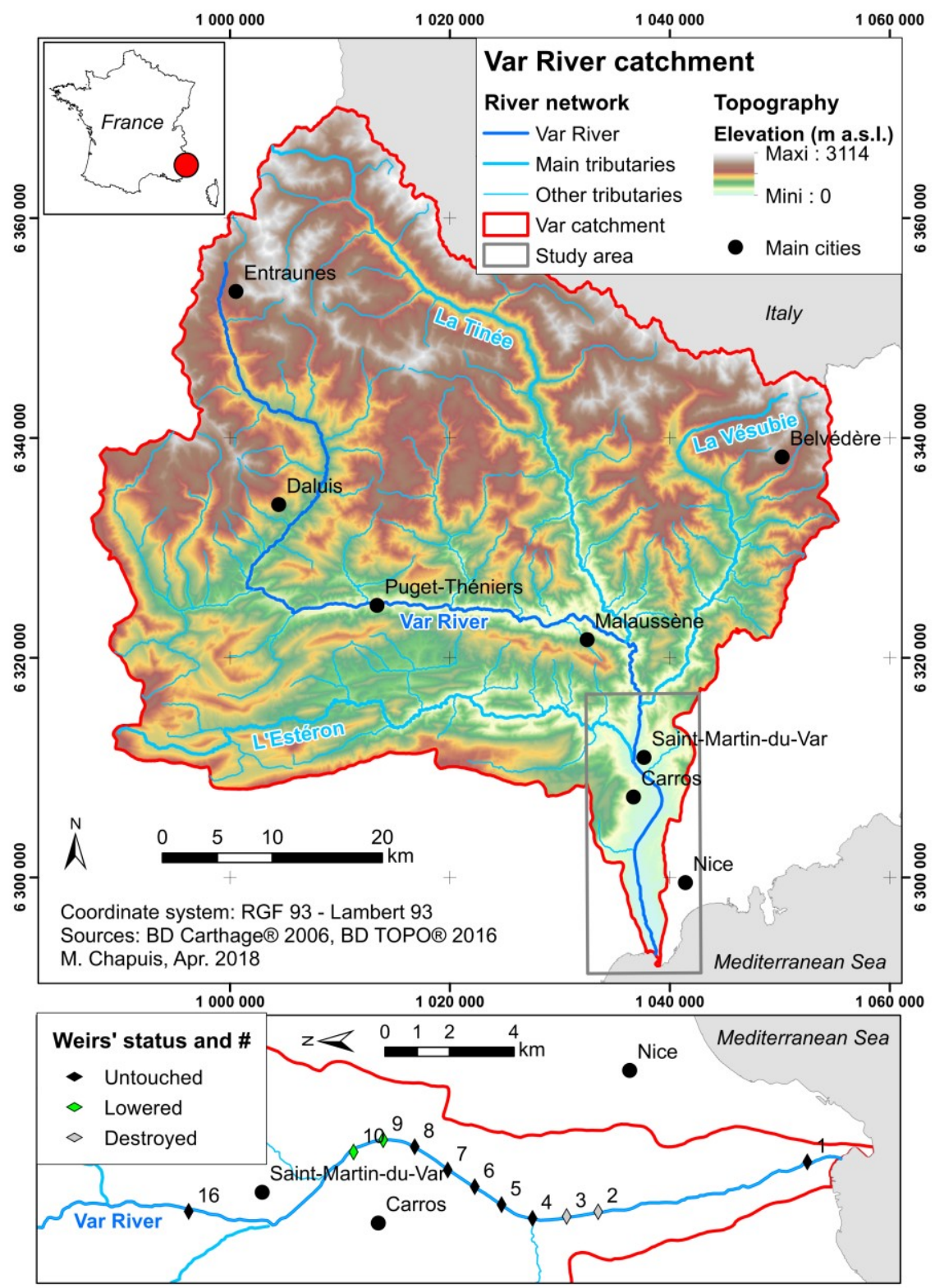

Fig. 1. Var River catchment and location of the study reach in the downstream part of the river. On the 11 weirs built within this reach, two were destroyed during the 1994 flood and two others are already lowered because of the ongoing restoration project. 
The downstream reach is characterized by heavy channelization that reduced active width from $1000 \mathrm{~m}$ to $250 \mathrm{~m}$ (fig. 2), and longitudinal profile stabilization (because of gravel mining) through several weirs. Initially 11 weirs were built in the 1970s [11], but weirs \#2 and \#3 were destroyed during the 1994 flood in the downstream end of the study reach (fig. 1).

Braiding was historically active in the floodplain because of sediment supply from the upstream catchment. Bed surface material is composed of gravel $\left(D_{50}=40 \mathrm{~mm}\right)$ with few patches of sand and silt, typical of braiding rivers in the area. Embankments for flood and lateral migration risk mitigation took place mostly after the second part of the $20^{\text {th }}$ century. In addition to gravel mining, embankments modified the fluvial pattern that shifted to wandering or even meandering and significantly reduced biodiversity [12, in 13].

The Var River is currently undergoing an ambitious restoration project that aims at restoring its 'natural' braiding pattern on the channelized downstream reach of the river. The restoration project started in 2009 and will continue for several years. It consists in lowering weir heights by $2 \mathrm{~m}$, as sediment continuity reconnection from upstream is obtained. To date, two weirs have been lowered: one in 2009 (weir \#9) and the other in 2012 (weir \#10). This project is expected to deliver multiple benefits to river ecosystems [6]: active braiding pattern and sediment continuity restoration, flooding risk mitigation, restoration of open landscapes that benefit to biodiversity, 'natural' and economical mitigation of vegetation encroachment and groundwater and surface water connectivity. The restoration operation is supported by numerical modelling [14] to assess the chronology of future channel evolutions that are mainly driven by the hydrological regime.
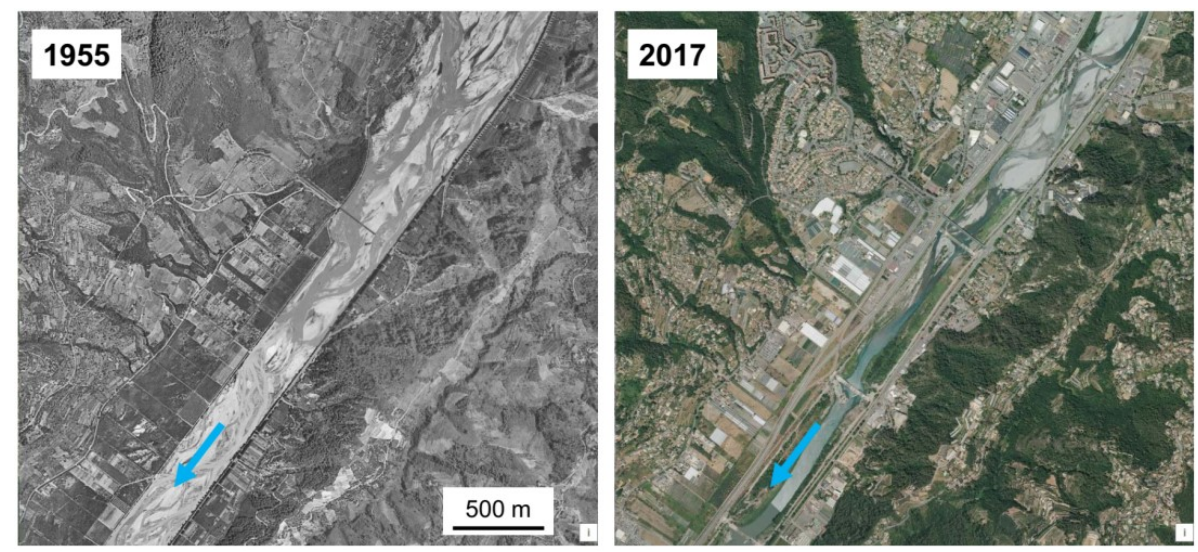

Fig. 2. Var River near Carros (pont de la Manda, weir \#7). The upstream part of the 2017 aerial photo shows part of the restored braiding pattern (modified from: https://remonterletemps.ign.fr).

\subsection{Methods}

LiDAR and orthophoto datasets were used to perform analyses for braiding rivers $[1,2]$ adapted to channelized rivers. For each combined dataset (2011-2012 and 2013-2014), we digitized morphological units based on orthophotos, then extracted elevation data from the LiDAR dataset and performed analyses ( $\mathrm{R}$ software environment) in order to extract morphological indicators within the study reach. Two main indicators were used:

- The Bed Relief Index (both normalized by catchment dimensions and not: $B R I^{*}$ [1] and $B R I$ [15], respectively) indicates elevation variability within a crosssection: 


$$
\begin{gathered}
B R I=\frac{1}{\left(x_{n}-x_{1}\right)} \sum_{i=1}^{n-1} \sqrt{\frac{\left(z_{i}-Z\right)^{2}+\left(z_{i+1}-Z\right)^{2}}{2}}\left(x_{i+1}-x_{i}\right) \\
B R I^{*}=\frac{1}{\left(x_{n}-x_{1}\right)} \sqrt{\frac{1}{n} \sum_{i=1}^{n}\left(z_{i}-Z\right)^{2}}
\end{gathered}
$$

where $Z$ is the mean elevation of the active channel, $z_{i}$ is the elevation at point $x_{i}$ and $x$ varies between bank toes, i.e. within the active width (fig. 3). More specifically, the $B R I^{*}$ indicates the ratio between the standard deviation of active channel elevations and the active channel width measured between bank toes [1].

- The active width $(W,[1,16]$, fig. 3$)$ : the normalized active width $\left(W^{*}\right)$ is a proxy for upstream sediment supply [17].

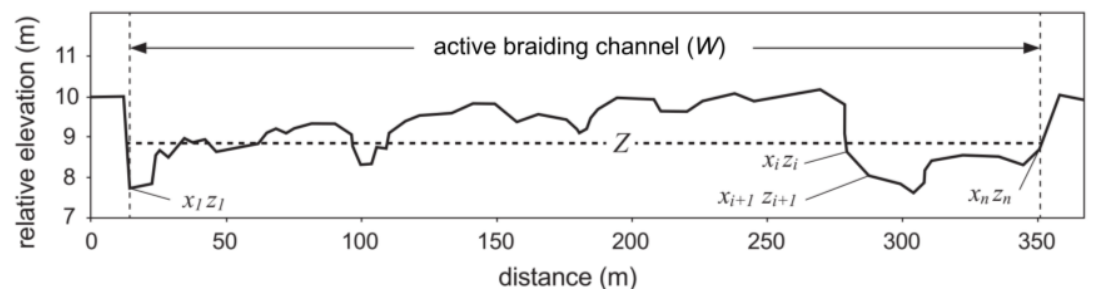

Fig. 3. Parameters extracted from channel cross-sections and used to calculate the $B R I$ and $B R I^{*}$ (modified from [1]).

Expected channel modifications due to weir lowering are (i) direct remobilisation of sediment stored behind the weir and (ii) upstream and downstream reactivation of sediment and bedforms' mobility. According to Leduc [18] and Liébault et al. [1], this is expected to generate lower values of $B R I$, locally higher values of active widths $(W)$ where lateral bars and/or terraces are reactivated by lateral mobility, and lower longitudinal $W$ variability.

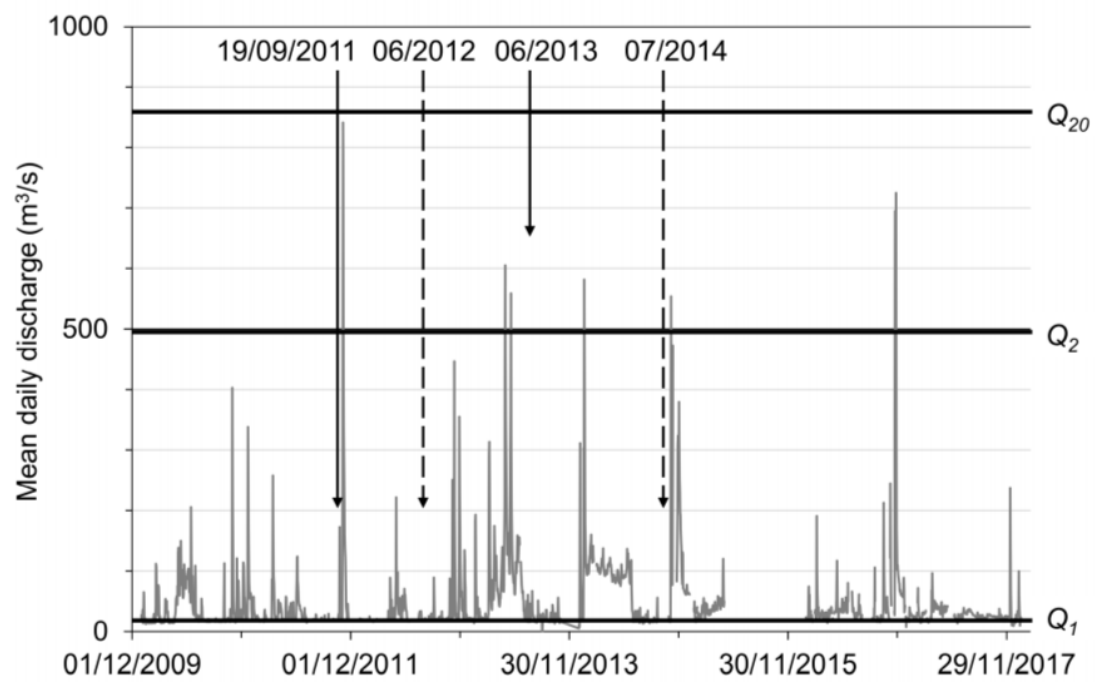

Fig. 4. Var River mean daily discharge during the 2010-2017 period at Carros gauging station (source: Banque Hydro). Values are regarded as 'doubtful' by the producer of this dataset, but the hydrograph general shape can still be considered valid. $Q_{i}$ refers to return period discharge: mean annual flow is estimated at $Q_{l}=52 \mathrm{~m}^{3} / \mathrm{s}$ (range: $\left.43-63 \mathrm{~m}^{3} / \mathrm{s}\right) ; Q_{2}=500 \mathrm{~m}^{3} / \mathrm{s} \quad\left(430-600 \mathrm{~m}^{3} / \mathrm{s}\right.$ ); $Q_{20}=860 \mathrm{~m}^{3} / \mathrm{s}\left(730-1200 \mathrm{~m}^{3} / \mathrm{s}\right)$. Dates for LiDAR campaigns correspond to solid arrows and for orthophoto campaigns to dashed arrows. 
Early in the analysis process, we stressed the importance of LiDAR and orthophoto datasets corresponding to a unique field campaign in order to prevent misinterpretation of morphological units during the digitization process (fig. 4). This shall be considered for future planning of data acquisition campaigns.

In this study, morphologic units were digitized from LiDAR datasets (2011 and 2013). We used aerial photos (2012 and 2014, respectively) only to recognize vegetation features (vegetated bars and islands) and to identify bed changes due to floods between the LiDAR and aerial photo campaigns. According to bed morphologic changes and sediment transport discontinuities, we defined four Var reaches as follow:

- Var 1 (0-4 km): morphology influenced by the Estéron confluence

- $\operatorname{Var} 2$ (6-10 km): restored reach (weirs \#9 and \#10 were lowered)

- Var 3 (10-15 km): unrestored reach, morphology still influenced by the destruction of weirs \#2 and \#3, see fig. 1

- $\operatorname{Var} 4$ (15-24 km): unrestored reach, morphology influenced by river mouth.

\section{Results and discussion}

The lower Var River is an active system that quickly recovers its sediment continuity from upstream thanks to the weirs' lowering restoration project (fig. 5): the 2011 dataset (before the lowering of weir \#10) shows high BRI values compared to the 2013 dataset.

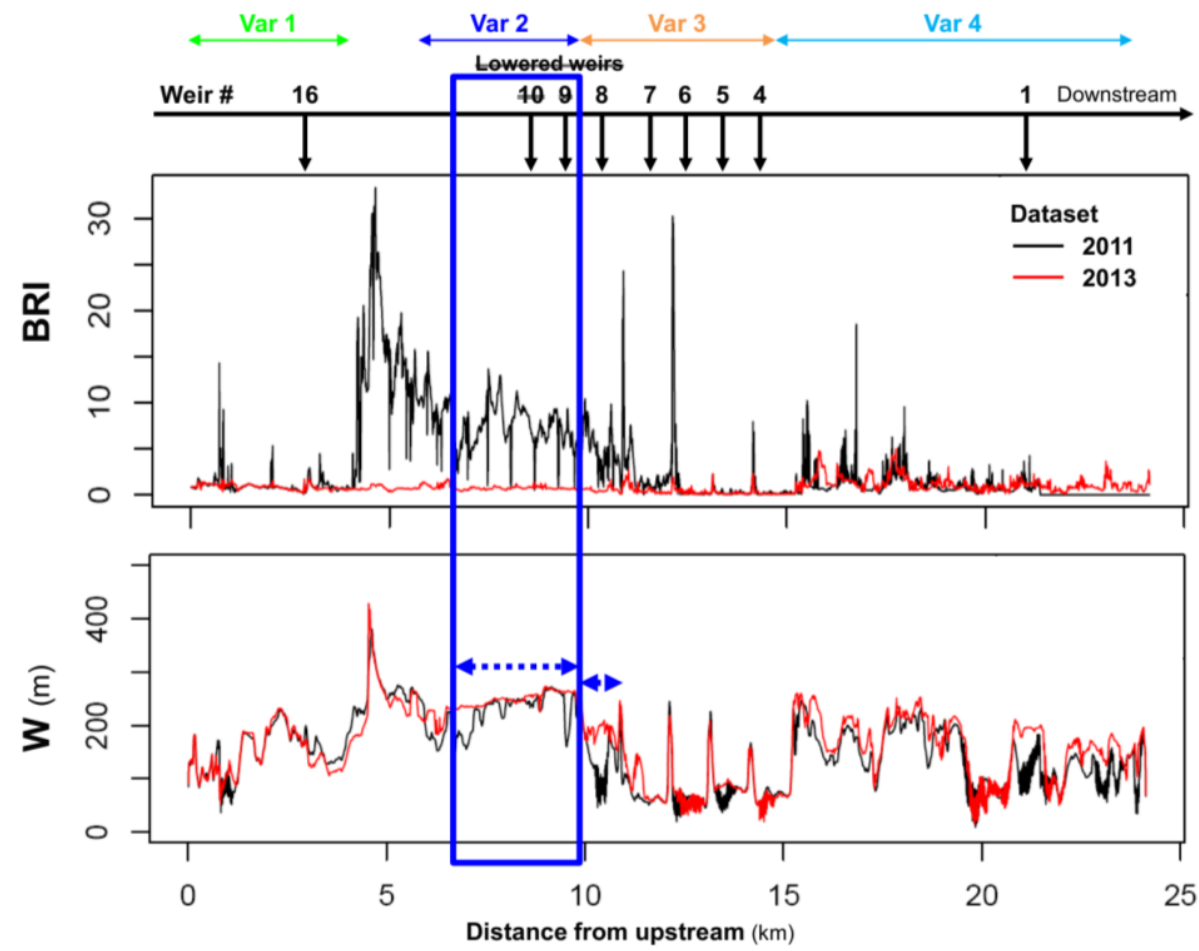

Fig. 5. Temporal analysis of river indicators: Bed Relief Index $(B R I)$ and active width $(W)$. Horizontal dotted arrows indicate reaches of relatively constant $W$ values in the 2013 dataset compared to 2011.

The 2013 dataset shows very low values of $B R I$, indicating low roughness within the cross-sections and thus a more active braiding pattern compared to 2011. The restored reach (Var 2) shows low change in $W$ between 2011 and 2013. This is consistent with the fact that, in a channelized river, braiding should generate more vertical (bed elevation 
changes) than horizontal (active width) bed reworking. $W$ tends to be more constant directly upstream and downstream the lowered weirs (fig. 5), indicating dynamic reaches: the upstream part of Var 2 reach matches $W=250 \mathrm{~m}$, which indicates that the Var is occupying the full width between lateral embankments.

Results for the 2013 channelized Var River dataset are plotted in fig. 6, along with laterally unconstrained braiding reaches in various French rivers in SE France [2]. Even when channelized, the Var reaches fit unconstrained braiding data. This should validate the use of $B R I$ and $W$ indices for channelized braiding rivers. Channelized reaches show high variability (high standard deviation) on both $B R I$ and $W$ values compared to unchannelized reaches. In the restored reach (Var 2), $W_{\text {restored }}=242 \pm 19 \mathrm{~m}$, while values range from $103 \pm 53$ to $163 \pm 53 \mathrm{~m}$ for 'unrestored' reaches. As for normalized bed relief index, $B R I^{*}$ restored $=0,003 \pm 0,001$ vs. $0,003 \pm 0,003$ to $0,007 \pm 0,004$ for 'unrestored' reaches. The 'restored' reach (Var 2) shows a different set of $B R I^{*}$ and $W$ indices, with a combination of low roughness and wide active width (high value of $W$ and narrow standard deviations for both $B R I^{*}$ and $W$ ) compared to nearby 'unrestored' Var reaches. The combination of $B R I$ and $W$ indices discriminates effectively between 'restored' and 'unrestored' reaches.

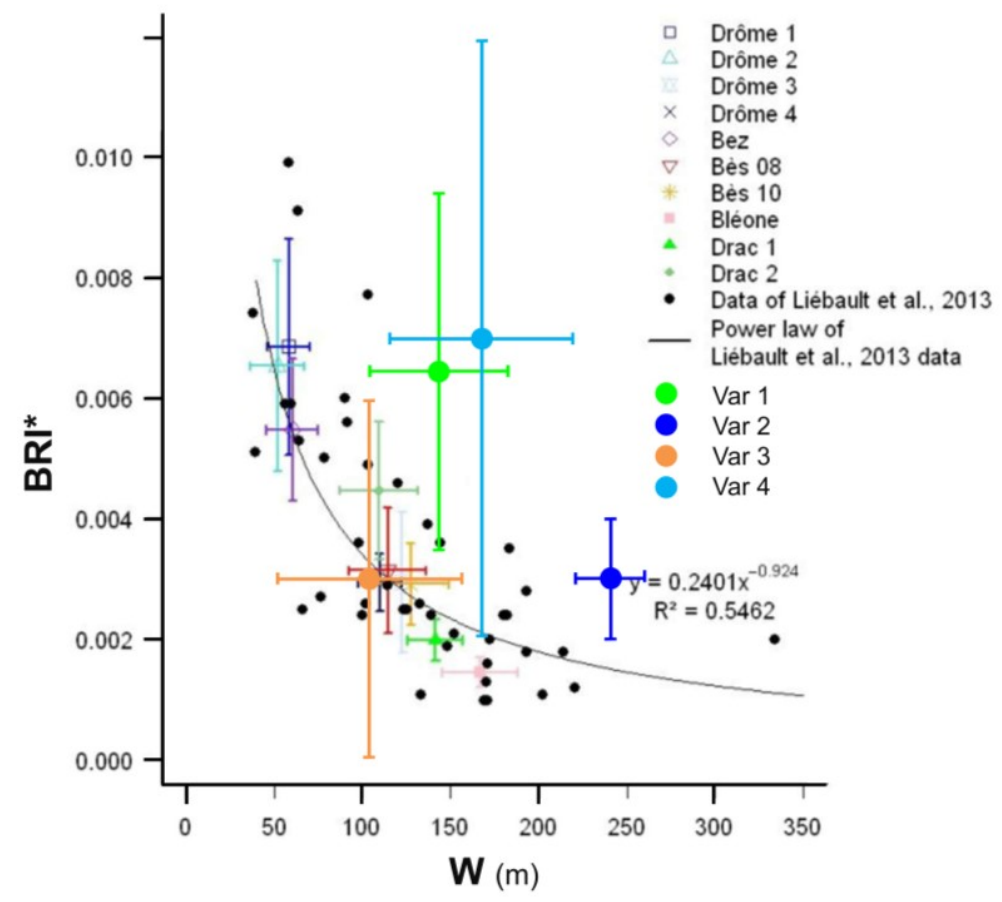

Fig. 6. Normalized Bed Relief Index $\left(B R I^{*}\right)$ and active width $(W)$ of the Var River reaches compared to unchannelized braiding rivers (modified from [2]).

\section{Conclusion}

The study led to a better understanding of the coupled dynamics between hydrology, sediment fluxes and morphology in a Mediterranean river. It also enabled to better assess the spatial and temporal influence of sediment transport discontinuities and disturbances.

The 'restored' reach shows a different set of indices compared to nearby 'unrestored' reaches. These indicators are thus promising in discriminating 'restored' vs. 'unrestored' reaches when used together: the combination of larger active width, and narrower standard deviations for active width and $B R I^{*}$, effectively discriminates the restored reach. 
Adapting existing methods from 'unconstrained' to 'channelized' braiding rivers widened the potential application of the tools developed by Lallias-Tacon [2] to modified braiding river systems in order to find quantitative indicators of morphodynamics and ecological functionality of a Mediterranean river. Further research should focus on additional indicators, such as those developed in Rinaldi et al. [19], as this study highlighted the relevance of combining several tools to achieve braiding river characterization in channelized reaches.

\section{References}

1. F. Liébault, S. Lallias-Tacon, M. Cassel, N. Talaska, River Res. Applic. 29, 1253-1266 (2013)

2. S. Lallias-Tacon. Analyse spatio-temporelle de la morphologie des rivières en tresses par LiDAR aéroporté (Université Lyon 2, France, 2015)

3. Agence de l'Eau Rhône Méditerranée Corse, Bassin du Rhône et des cours d'eau côtiers méditerranéens: caractérisation du district et registre des zones protégées adopté par le comité de Bassin du 4 mars 2005: état des lieux (Comité de bassin Rhône Méditerranée, 2005)

4. Maison Régionale de l'Eau, SOGREAH, H. Gomila, ASCA Consultants, Définition d'une méthode de caractérisation des cours d'eau de type méditerranéen et application dans le cadre de la DCE (Agence de l'Eau Rhône Méditerranée Corse, 2007)

5. B. Terrier, S. Stroffek, Guide technique du SDAGE - Délimiter l'espace de bon fonctionnement des cours d'eau (Agence de l'Eau Rhône Méditerranée Corse, 2017)

6. MA. Leibold, M. Holyoak, N. Mouquet, P. Amarasekare, J.M. Chase, M.F. Hoopes, R.D. Holt, J.B. Shurin, R. Law, D. Tilman, M. Loreau, A. Gonzalez, Ecology Letters 7, $601 \mathrm{e} 613$ (2004)

7. T. Datry, N. Bonada, J. Heino, Oikos 125, 149e159 (2016)

8. H. Piégay, N. Lamouroux, J. Environ. Manag. 202, 333-336 (2017)

9. Commission Locale de l'Eau nappe et basse vallée du Var, Schéma d'Aménagement et de Gestion des Eaux de la Nappe et Basse Vallée du Var: plan d'aménagement et de gestion durable (Département des Alpes-Maritimes, Direction de l'Environnement et de la Gestion des Risques, Nice, 2015)

10. M. Chapuis, D. Collomb, Revue Méditerranée 118, 65-74 (2012)

11. E.J. Anthony, Revue Méditerranée 108, 91-97 (2007)

12. M. Peipoch, M. Brauns, F.R. Hauer, M. Weitere, H.M. Valett, BioScience 65, 10571065 (2015)

13. F.R. Hauer, H. Locke, V.J. Dreitz, M. Hebblewhite, W.H. Lowe, C.C. Muhlfeld, C.R. Nelson, M.F. Proctor, S.B. Rood, Science Advances 2, e1600026 (2016)

14. C. Thomas, E. Tiriau, TSMR Conference (Lyon, France, 2017)

15. T. B. Hoey, A. J. Sutherland, Earth Surf. Process. Landforms 16, 447-462 (1991)

16. H. Piégay, A. Alber, L. Slater, L. Bourdin, Aquat. Sci. 71, 371-388 (2009)

17. B. Belletti, S. Dufour, H. Piégay, River Res. Applic. 31, 1-15 (2013)

18. P. Leduc, Étude expérimentale de la dynamique sédimentaire des rivières en tresses (Université de Grenoble, France, 2013)

19. M. Rinaldi, B. Belletti, M. Bussettini, F. Comiti, B. Golfieri, B. Lastoria, E. Marchese, L. Nardi, N. Surian, J. Environ. Manag. 202, 363-378 (2017) 